\title{
12
}

\section{Conclusions and implications}

The small states agenda proposed in the Commonwealth/World Bank Joint Task Force Report of April 2000 and the review of this agenda, 'Toward an outward-oriented development strategy for small states: issues, opportunities and resilience building', of August 2006 both identify serious challenges for development in small states due to their small size, remoteness and vulnerability. The review suggests that over the past few years, the prospects for small states have deteriorated further due to preference erosion and the emergence of new, large competitors. It proposes that small states need to reposition themselves in the global economy and move into knowledge-based and other service industries. This book discusses the challenges faced in doing this and how they might be overcome. Growth strategies in the new competitive environment will increasingly rely on the promotion of knowledge-based and service industries.

Small states differ - some are landlocked while others are islands or coastal states, some are remote to key markets, others have the benefit of large neighbours and income levels vary. Services are already an important contributor to income and employment in small states. The poorest small states face severe constraints to services development, but even they are heavily dependent on the services sector. The small states in the middle and particularly the high-income group have already moved significantly into services, and some have specialised in highly-skilled, knowledge-based services more than their large state peers.

For many small states, trade in services, especially tourism-related services, is already an important foreign exchange earner. Tourism is highly important for low- and middleincome small states due to their relatively less diversified services sectors as compared to those in high-income states. A major challenge is to move up the value-added chain towards knowledge-intensive services. Generally, the more developed a country, the more it is engaged in knowledge-based services. This finding is reiterated by the six case studies, where the authors observe that tourism typically accounts for over 50 per cent of service exports for the middle-income countries (Botswana, Mauritius, St Lucia and Vanuatu); this is also the case (although to a lesser extent) in Singapore and United Arab Emirates (UAE). Singapore's service exports are skill intensive, and include education services, financial services and other professional business services such as information technology (IT). UAE's major service is trade (external, wholesale and retail), which has developed due to its excellent transport infrastructure facilities; however, the country is rapidly developing its financial, educational and tourism services as well. 
Developing trade in knowledge-intensive services is a complicated process and many countries do not have an explicit trade-in-services policy or a detailed overall plan to develop trade in services. The constraints to trade in services are complex and go beyond traditional trade constraints. A policy-relevant approach distinguishes amongst three types of constraints. These include:

- supply-side or domestic capacity constraints;

- the domestic regulatory and institutional framework; and

- external constraints (for example, international trade in services agreements or pressures due to competition).

This approach is particularly useful in the services context for several reasons. It provides an analytical lens to developing trade in services - trying to make sense of the myriad of constraints to trade in services. It also delineates clear responsibilities for different actors in different sectors, ministries and among other stakeholders. That said, trade in services, which is a catalyst to promote economic diversification away from traditional sectors, involves a fundamental shift in mindset throughout the whole economy and necessitates different types of actions to overcome these constraints. For this to be successful, leadership or co-ordination from the top is crucial. Small countries might be at an advantage because they may have more flexibility to introduce changes than their larger peers.

A review of the experiences of small states that have either developed or are in the process of developing a strong services sector, in the context of these constraints, shows how appropriate public support may help to build vibrant private services sectors. The small states studied - Botswana, Mauritius, St Lucia, Singapore, United Arab Emirates and Vanuatu - belong to different geographical locations and income groups. The studies covered the performance and supporting factors in five promising services: financial, information and communications technology (ICT), education, professional business and tourism.

\section{Botswana}

Botswana, a landlocked country in Africa with foreign exchange earnings heavily dependent on diamonds and beef, has tried actively to move into financial services by establishing an International Financial Services Centre (IFSC). This has had some success as some IT and financial firms have moved in, but further progress seems arrested by weak IT systems and lack of appropriate skills. Call centres and the regional headquarters of some financial firms have already moved to Johannesburg instead. Banks list Botswana's lack of skilled labour as one of their primary concerns, an issue worsened through the strict immigration regime that affects not only unskilled but also skilled workers. The country has undertaken some important public-private initiatives to improve tertiary education, as in the Botswana Accountancy College: here an initiative has reduced dependence on imports of education services by training registered accountants, such that numbers have increased from four in 1996 to 400 a 
decade later. However, there are still too few efforts to improve ICT infrastructure and the availability and quality of local skills to make Botswana the regional hub of financial services and increase the net export of services. Perhaps the current plans for an IT hub could improve this.

\section{Mauritius}

Mauritius has managed the development of its services sector by gradually adding tourism, financial services and EPZs to the two traditional pillars of the economy, sugar and textiles. It has now embarked on a plan to provide an integrated competitive platform, linking the various pillars of economic development. The rapid expansion of services has already absorbed (employment) losses stemming from agriculture and textiles that were previously dependent on preferences, although there will still be painful losses in the adjustment process. The tourism sector has developed well and has set very ambitious new targets. The government is encouraging and adopting innovative ways to develop new types of tourism activities and attract foreign investment. Mauritius is also successfully developing its IT and financial services, benefiting from useful government involvement such as forward planning in terms of infrastructure, as well as from external technical and financial support. However, a cause of concern is the low supply of appropriately trained labour needed for the knowledge-based service economy. Increasing relevant tertiary enrolment rates is one of the country's national priorities.

\section{St Lucia}

St Lucia is currently at a critical juncture, as trade preferences are being eroded and competition with bigger countries such as Brazil, India and China is intensifying in international markets. The country has already realised a limited diversification of its export base by successfully promoting tourism, which it has done by using a proactive supply of infrastructure as well as organising successful one-off events such as St Lucia Jazz and the St Lucia Carnival. However, its performance in other, more knowledgebased services remains weak and while there are signs of other emerging sectors (ITenabled services and offshore education), they are not yet receiving the same integral support and strategic planning as the tourism sector. To actively move trade in services beyond tourism, St Lucia will need to provide the emerging sectors with at least the same level of support (for example, improved infrastructure, promotion of service associations and effective state-business relations, and appropriate and well targeted investment incentives) and strategic direction as it did to tourism. In addition, there is still a lack a focus on developing a strong human resource skills base in order to move into a knowledge-based service industry.

\section{Singapore}

Singapore is an important success story for small states striving to build a strong services sector. The public sector created the right environment (a business-friendly 
climate, an export-oriented economic policy framework, improved regulatory and legal systems and state-led investments in strategic sectors through proactive supply of infrastructure, planning of clusters and skill upgrading schemes) for the services sector to develop. The case study shows that a successful approach needs the ability to respond flexibly as well as long-term engagement. The support framework has evolved gradually over time from one that stimulated manufacturing in the 1960s to one that promoted a knowledge economy in the 1990s and beyond. Singapore has a competitive advantage over many large countries in terms of its excellent transport and ICT infrastructure and availability of a skilled labour force. The government is attaching particular emphasis on promoting the education sector even further to make Singapore the regional hub for educational services. This would further strengthen other knowledge-based services such as ICT and financial services.

\section{United Arab Emirates}

United Arab Emirates (UAE), particularly the emirates of Dubai and Abu Dhabi, is a rapidly emerging success story. Like Singapore, the public sector in UAE, backed by oil revenues that one day will run out, took the lead to identify services with potential and development opportunities, planned strategically and created an investment-friendly climate to attract foreign investment. One of the successful initiatives was that of an open skies policy liberalising air transport, which strengthened the tourism sector and stimulated the demand for other goods and services as well. A more recent and sudden change has been the increased focus on developing knowledge-based services, with Dubai leading the other states in this regard. Important initiatives include the Dubai Financial Centre, Dubai Knowledge Village and Dubai Internet City. Dubai and Singapore have in common a strong focus on attracting (foreign) talents and foreign business schools and universities.

\section{Vanuatu}

Vanuatu, classified as a least-developed country (LDC) because of its high economic and environmental vulnerabilities, has an economy that is highly dependent on the services sector, yet exports of services have remained low and stagnant. The country continues to rely on primary agricultural products for foreign exchange. An offshore financial services sector was established as early as 1971 at Port Vila, which has attracted considerable foreign investment - in part because of extensive fiscal and legal incentives. However, considering increasing international competition to attract foreign investment in financial services, Vanuatu needs to be more proactive beyond incentives. Development of ICT infrastructure and human capital, as well as international marketing, are important in attracting more investment, especially from Asia. The government has actively promoted tourism in recent years and the contribution of tourism-related activities to the economy is rapidly expanding. Considering that Vanuatu is one of the most disadvantaged economies in the world in terms of its geographic location and susceptibility to natural disasters, and that it relies heavily on official development assistance, the development of a sound services sector requires strategic 
planning at the national level, as well as international technical and financial assistance to build domestic capacity.

\section{Strategic and practical implications}

The book includes a number of important strategic and practical implications:

- It makes economic sense for small states to concentrate on the development of knowledge-intensive services. Such services are less sensitive to high transport costs when compared to goods, help diversify the economic base, reduce vulnerability to macro shocks, are less sensitive to hurricanes (compare a call centre with a plantation) and reduce reliance on agriculture and manufacturing, which depend on eroding trade preferences and scale. With good telecommunication systems, ITenabled services in small states can obtain direct access to large markets.

- The reality is that while many small states already depend on services for income, exports and jobs, this is often due to tourism, and less so because of the development of other services.

- Successful examples show that leadership is required to create a vision for the development of the services sector in a country. This may lead to a change in the mind-set throughout the whole economy towards a competitive, service-dependent economy and away from preference-dependent and protected sectors.

- Small states that have successfully developed knowledge-based services have supported these sectors consistently over a period of years and decades, while at the same time remaining flexible to adjust to new internal and external challenges.

- Technical and financial assistance could help to enable small states to adjust to a higher value-added economy and away from preference-dependent economies, especially 'Aid for Trade'. Many small states are amongst the most disadvantaged countries in the world in terms of their economic and environmental vulnerabilities. Regional and international co-operation to devise appropriate plans to build domestic capacity and improve physical and human infrastructure is crucial for these states. There also exists a large gap between small states in the low-income group and other small states in terms of their capacity to embrace service industries.

- There are various supporting factors (domestic capabilities, regulatory frameworks, external conditions etc.) across countries and sectors:

\section{Different sectors}

- Tourism activity is often private-sector driven initially, but the public sector can support tourism by building infrastructure and co-ordinating the activities of different private sector agents (for example, as in St Lucia). The design of appropriate international trade-related policies can be instrumental in this regard. The success 
of the open skies policy of Dubai (UAE) demonstrates how such liberalisation tends to work well.

- Some small states, especially middle and high income, are moving fast into knowledge-based services beyond tourism services. For example, Mauritius has already experienced a rapid rise in the number of IT companies operating in the country. However, in other small states the government needs to consider following an active approach to support services, as even a small expansion requires an increase in domestic capabilities such as skills and improved IT networks. If a deliberate attempt is not supported on all fronts, IT companies may decide to move elsewhere (see, for example, Botswana).

- Some small states have been successful at becoming regional financial hubs (for example, Singapore, Dubai and Mauritius). Others have long been engaged in offshore finance (for example, the Bahamas, Barbados and Vanuatu). However, many small states have struggled. It is important to realise that an adequate regulatory framework is not sufficient to succeed, as late entrants find it difficult to beat the competition.

- Offshore education and training is another emerging service. Caribbean states have already been successful in attracting offshore medical schools and they can contribute significantly to gross domestic product (GDP). Small states could approach this sector more strategically and create 'sticky' places where investors invest in education (for example, training local and foreign nurses), which would improve exports of services and at the same time upgrade the skills of the local workforce appropriate for the development of the services sector.

- There are many other exports of services from small states, including professional services, but often there are no systematic data. The lack of available data suggests that such services may not receive priority policy support. A first step would be to compile data and assess the export capacity of these sectors. Considering the increase in global demand for business services, such sectors can play an important role in diversifying the economies of small states.

\section{Different supporting factors}

- Building an appropriate and flexible supply capacity is crucial. Although this is part of normal development policies (skills enhancement, infrastructure, ICT etc.), the situation is different for small states, which face stark choices because of their small size and limited resources. Diverting resources from traditional sectors such as agriculture and manufacturing to supporting key services may involve adjustment costs for the economy, which will cause political repercussions and economic costs for some. Agreement on priority sectors is required within the country and careful planning as well as execution of policies to minimise the adjustment costs and maximise the advantages of diversification. 
- The regulatory framework is very important for services. In some cases, bad frameworks can stifle development (for example, lack of regulation of monopolies in the utilities sector in the Caribbean). In other cases, a change in the rules can enable new service activities (attraction of offshore schools, film sets etc.).

- Small states need to embrace globalisation and use international trade negotiations to signal openness and their forward-looking approach. None of the countries studied have experienced negative consequences from taking part in trade in services negotiations, which have actually caused the private sector to take competition seriously. Creating a transparent framework for the non-discriminatory treatment of domestic and foreign investors is important if small states are to attract significant foreign (and local) investment in services. Successful small states tend to be more active in regional service negotiations, trying to gain access for their services providers in mode 4 negotiations on temporary migration.

- Governments have also considered the institutional support structure of both the private and public sectors. Private sector organisations can be assisted, perhaps with initial endowments or continued project support. Coalitions of service industries can also play a useful role in small states through, for example, educating their members about international service conditions and policies; promoting the adoption of standards and codes of conduct of their members to prepare for competition; lobbying government on the importance of an appropriate environment for services; and assessing the capacity of the sector and identifying areas with market potential.

Overall, the development of services involves leadership that can signal a fundamental shift in economic thinking in small states, which have traditionally relied on preferences and protection of goods. Changes in policy might be required at all levels: trade negotiations, the development of an appropriate supply capacity and building an appropriate domestic regulatory framework. State-business relations need to be strengthened so that the private sector benefits further from initiatives undertaken by the government. Engagement with the international economy is crucial, so that important lessons can be learned from the experiences of other countries in general and successful small states in particular. In addition, the international community can help by supporting such initiatives and assisting small states technically as well as financially to build the domestic capacity that supports a strong services sector crucial for future growth prospects in small states. Small states need to be proactive and consistent, yet flexible in their approach. 'Aid for Trade' can support this. 
